\title{
PENGALAMAN PENGGUNA, KEAMANAN TRANSAKSI, KEMUDAHAN PENGGUNAAN, KENYAMANAN, DAN PENGARUHNYA TERHADAP PERILAKU PEMBELIAN ONLINE SECARA IMPULSIF
}

\author{
Didit Darmawan', Arif Rachman Putra ${ }^{2}$ \\ Universitas Mayjen Sungkono ${ }^{1,2}$ \\ Email : dr.diditdarmawan@gmail.com, arifrachmanputra.caniago@gmail.com
}

\begin{abstract}
In Indonesia, online shopping has become a trend and transactions have increased drastically, marked by the development of business players involved in the online marketplace industry, one of which is Lazada, which is the top marketplace in Indonesia. Lazada is an online product buying and selling application that offers a variety of products and uses the internet and social media as a forum for interactive two-way interactions with its users. Product bids, attractive prices and availability of information can lead to impulsive buying behavior. The impulse to buy impulsively is described as a complex, sudden, pleasant purchase and the decisionmaking process occurs instantaneously without thinking of any other considerations. This study has the main objective of identifying the effect of user experience, transaction security, ease of use, convenience on impulsive online buying behavior aimed at the Lazada marketplace. The population in this study are consumers who have made online purchases at Lazada. The sampling technique used is non-probability sampling, with a purposive sampling method with the following sample criteria: consumers who have made online Lazada purchases more than once, and aged over 17 years to 50 years. Respondents came from the city of Sidoarjo and totaled 120 people. Multiple linear regression analysis is an analytical tool used in this study. The t test is to prove the research hypothesis which previously carried out the reliability test. From the results of the analysis of the research results, it is found that experience, safety, convenience and comfort have a significant influence on impulsive buying behavior at Lazada. The experience variable is a variable that has a dominant effect.
\end{abstract}

Keywords: experience, security, ease of use, enjoyment, impulsive buying behavior.

\section{Pendahuluan}

E-commerce menunjukkan perkembangan pesat terutama di industri ritel yang berhubungan dengan para pengguna akhir. Di Indonesia, perilaku belanja secara online dipicu oleh salah satu faktor kemunculan marketplace yang menyediakan platform yang mudah dioperasikan bagi pengguna. Selain itu beragam toko online memiliki pengunjung yang besar yang mendukung perkembangan toko menjadi lebih 
cepat. Kegiatan berbelanja secara online dirasakan lebih mudah dan menghemat waktu dibandingkan secara langsung ke tempat pembelian (Darmawan, 2008). Konsumen merasa nyaman, aman dan mengandalkannya.

Di Indonesia, belanja online telah meningkat secara dratis dengan ditandai dengan berkembanganya pelaku-pelaku bisnis yang terlibat di industri online marketplace seperti Tokopedia, Shoope, Lazada, Blibli, dan Bukalapak. Hal tersebut membuat masyarakat tertarik untuk melakukan pembelian secara online sehingga tidak memerlukan waktu yang banyak untuk bertemu dan mengantri saat proses membeli. Transaksi perdagangan online di Indonesia pun semakin meningkat dan menjadi tren di masyarakat.

Lazada merupakan marketplace papan atas di Indonesia dan aplikasi jual-beli produk secara online dengan tawaran beragam produk. Keunggulan top brand lebih mudah melakukan komunikasi kepada target pasar (Darmawan, 2005). Lazada menggunakan hubungan antara penjual dan pembeli dengan cara yang efektif juga dapat saling berhubungan dan melakukan berbagai promosi untuk meningkatkan jumlah pengunjung di platformnya. Tawaran produk dan harga yang menarik dapat menyebabkan perilaku pembelian yang tidak direncanakan. Berbagai stimulus dari platform online dengan penawaran menarik dan mendorong keinginan konsumen membeli semakin besar meski mereka tidak memiliki rencana untuk membeli atau memang barang tersebut tidak terlalu penting (Khasanah et al., 2010). Mereka mungkin hanya mengikuti keinginan akan perasaan untuk membeli suatu barang menarik. Hal ini merupakan bentuk dari perilaku konsumen sebagai masalah yang paling kompleks dari teori dan praktik pemasaran karena heterogenitasnya yang mencolok dan banyak faktor yang memberikan dampak gabungan padanya, dengan cara yang kurang lebih beragam, tergantung pada kesempatannya. Manifestasi yang spesifik dari perilaku konsumen di pasar adalah perilaku pembelian impulsif yang berarti pembelian tanpa direncanakan.

Pembelian yang tidak terencana, menarik dan kompleks secara hedonis dapat menggambarkan sebagai perilaku pembelian impulsif. Terkadang pelanggan tidak berfikir secara cermat untuk melakukan pembelian impulsif karena pada saat itu mereka hanya mengikuti perasaan akan ketertarikan suatu produk tanpa 
memikirkan kebutuhan atau hanya keinginan (Darmawan, 2021 ${ }^{\mathrm{a}}$ ). Tindakan membeli tanpa terencana ini sudah menjadi kebiasaan dapat dikatakan sudah menjadi gaya hidup yang sudah menular pada semua konsumen, semua itu disebabkan oleh kemajuan teknologi pemasaran dan pertumbuhan e-commerce yang pesat. Salah satu studi menyebutkan bahwa diperkirakan sekitar $40 \%$ dari semua pengeluaran konsumen online disebabkan oleh pembelian impulsif online (Liu et al., 2013). Peneliti berpendapat bahwa lingkungan belanja online sekarang lebih kondusif untuk perilaku pembelian impulsif daripada secara offline (Eroglu et al., 2001), semua dikarenakan oleh keadaan disaat transaksi online, misalnya konsumen tidak akan terpengaruh oleh jauhnya lokasi, jam buka toko, ketidaknyamanan akan pegawai toko, atau bahkan ketidaknyamanan akan toko, yang mungkin saja hal itu dialami oleh konsumen saat berbelanja secara langsung.

Perilaku pembelian impulsif dianggap penting bagi mereka pelaku usaha sehingga pelaku usaha dapat membuat iklan-iklan yang menarik dan pemasaran dengan cara komunikasi efektif pada platform mereka mengenai produk yang dipromosikan. Pembelian secara spontan dapat dilakukan konsumen dikarenakan promosi-promosi yang dilakukan oleh pelaku usaha tersebut. Adanya perilaku bentuk ini yaitu pembelian impulsif dalam belanja online harus dimanfaatkan sebaik-baiknya oleh para pelaku usaha (Purnamasari et al., 2002). Mereka harus dapat memberikan jaminan keamanan dan kenyamanan dalam bertransaksi serta kemudahan penggunaan. Pengalaman pun menjadi faktor yang turut berpengaruh terhadap perilaku pembelian online secara impulsif (Iskandar, 2003). Hal-hal tersebut perlu diperhatikan oleh para penyedia jasa di marketplace agar terbina hubungan jangka panjang dengan para pengguna. Oleh karena itu, studi ini memiliki tujuan utama yaitu mengidentifikasi pengaruh empat variabel bebas terhadap perilaku pembelian online secara impulsif yang tertuju pada marketplace Lazada. Variabel bebas tersebut adalah pengalaman pengguna, keamanan transaksi, kemudahan penggunaan, dan kenyamanan.

\section{Tinjauan Pustaka}

\subsection{Pengalaman Pengguna}


Pengalaman berbelanja dapat memberikan pengaruh terhadap perilaku lanjutan. Begitu pun terjadi pada perilaku belanja online (Parasuraman dan Zinkhan, 2002; Mathwick et al., 2001). Menurut Elliot dan Fowell (2000), bertambah besarnya belanja online disebabkan oleh pengalaman yang didapatkan konsumen tentang internet. Menurut Shim dan Drake (1990), mengatakan bahwa pelanggan mempunyai niatan yang besar untuk membeli secara online dikarenakan oleh pengalaman pembelian sebelumnya sehingga hal tersebut membuat konsumen kehilangan keraguan akan hasil produk yang akan dibelinya. Ada peluang lebih besar melakukan pembelian dari mereka yang telah mengalaminya. Mereka yang mempunyai catatan pembelian sebelumnya secara online akan lebih memilih untuk melakukan pembelian ulang secra online dibandingkan dengan konsumen yang baru mencoba untuk melakukan pembelian online (Darmawan, 2021 ${ }^{\mathrm{b}}$ ). Adanya pengalaman pembelian online terdahulu yang menghasilkan kepuasan akan mendorong konsumen untuk terus melakukan pembelian secara online kedepannya (Shim et al., 2001). Sebaliknya, mereka dengan pengalaman masa lalu yang buruk menyebabkan ketidaktertarikan untuk melakukan pembelian online kembali. Hal ini menunjukkan perlunya upaya untuk membuat konsumen pembelian online menjadi tertarik melakukan pembelian ulang dengan cara memberikan pengalaman yang memuaskan saat berbelanja online (Weber dan Roehl, 1999). Dapat disimpulkan bahwa pengalaman berbelanja online konsumen berpengaruh signifikan terhadap niat beli untuk berbelanja online kembali v(Shim et al., 2001).

\subsection{Keamanan Transaksi}

Secara umum, konsep keamanan transaksi mengacu pada kemampuan untuk melindungi terhadap ancaman potensial. Namun, di lingkungan online, keamanan didefinisikan sebagai kemampuan dari website perusahaan online untuk melindungi informasi konsumen dan data transaksi keuangan mereka dicuri selama terjadi hubungan diantara mereka (Darmawan, 2021 a). Raman dan Viswanathan (2011), menyatakan bahwa inti dari transaksi internet adalah kemanan. Keamanan yang dimaksud adalah bagaimana kemampuan toko untuk melaksanakan kendali dan menajaga kerahasiaan terhadap transaksi online yang dilakukan konsumen pada 
data yang telah mereka berikan (Park dan Kim, 2006). Keamanan pembelian dengan menggunakan internet merupakan faktor kunci yang menjadi perhatian pembeli karena seluruh transaksi dilakukan menggunakan internet. Persepsi keamanan menurut konsumen mengarah kepada kerahasiaan dan ketidakbocoran data pribadi yang telah mereka berikan sehingga dapat terjaga, tidak terlihat, tidak dapat disimpan dan disalah gunakan oleh pihak yang tidak dapat mempertanggungjawabkan tindakannya (Chellapa dan Pavlou, 2002). Persepsi keamanan telah ditemukan menjadi penentu niat konsumen untuk melakukan transaksi di situs e-commerce (Pavlou 2001). Faktanya, keamanan dapat dianggap sebagai prioritas teratas, jika bukan teratas, untuk pengguna web, terutama untuk domain e-commerce (Zhang dan Von Dran, 2002).

\subsection{Kemudahan Penggunaan}

Kemudahan penggunaan (ease of use) mengarah kepada seberapa jauh calon pembeli atau pengguna layanan berharap akan bebas dari target kecurangan dan kesalahan (Davis 1989). Hal ini berarti kesan tentang sejauh mana seseorang percaya sistem digunakan dengan kemudahan sehingga dengan mudah tidak terjadi kesulitan. Kemudahan penggunaan berhubungan dengan penerimaan web dan cara mengopersikan situs web yang yang tidak perlu menggunakan upaya lebih. Situs web yang baik dan tertata akan memudahkan dalam proses pengoperasiannya (Darmawan 2021 ${ }^{\mathrm{a}}$ ). Kemudahan penggunaan merupakan penentu penting dari niat individu untuk menggunakan sistem (Davis 1989) atau peneliti lainnya telah menguji dan menemukan dukungan untuk hubungan antara persepsi kemudahan penggunaan dan niat untuk menggunakan sistem dalam konteks e-commerce (Van der Heijden 2003; Vijayasarathy, 2004). Kemudahan penggunaan menentukan keberlanjutan hubungan antara pembeli dan penjual berkaitan dengan perilaku belanja online. Menurut Darmawan (2012), penggunaan aplikasi yang mudah merupakan hal yang perlu diperhatikan oleh penyedia, hal itu didasari oleh pembeli di e-commerce memiliki tingkat kemudahan yang berbeda, mulai dari kemudahan untuk mengakses suatu barang, kemudahan untuk melakukan transaksi pembayaran, 
kemudahan untuk melakukan pembelian dan pemilihan untuk pengiriman barang. Berdasarkan studi sebelumnya, kemudahan penggunaan memiliki pengaruh terhadap keputusan pembelian online. Hal tersebut ditunjukkan oleh Chen dan Li (2007); Cho dan Sagynov (2015); dan Kucukusta et al. (2015).

\subsection{Kenyamanan}

Pembelian spontan juga bisa terjadi karena terdapat tindakan berdasarkan reaksi kognitif (perceived usefulness) juga (perceived enjoyment dan pleasure) berasal dari rangsangan yang didapatkan. Reaksi kognitif dan afektif yang terjadi pada konsumen saat terjadi interaksi dengan web akan menentukan respon konsumen (Karina et al., 2012). Semakin banyak rangsangan yang diperoleh konsumen maka semakin besar peluang mereka untuk melakukan pembelian impulsif (Shen dan Khalifa, 2012). Kenyamanan mengarah pada motivasi

(Park et al., 2012). Motivasi atau kenikmatan intrinsik berasal dari berdasarkan penilaian suatu pengalaman guna kepentingan masing-masing, terlepas dari akibat lain yang akan timbul (Holbrook, 1994). Kenyamanan dihasilkan dari kesenangan dan keseruan dari pengalaman belanja online, bukan dari penyelesaian tugas belanja. Pembelian barang mungkin tidak disengaja dengan pengalaman berbelanja online (Darmawan, 2004). Hal ini menunjukkan kesan konsumen mengenai potensi hiburan dari belanja internet. Childers et al. (2001) menemukan ketenangan sebagai prediktor yang konsisten dan bertenaga menurut perilaku terhadap belanja online. Apabila konsumen menikmati pengalaman belanja online, mereka mempunyai perilaku yg lebih positif terhadap belanja online dan lebih cenderung mengadopsi internet menjadi media belanja. Ada tiga dimensi kenyamanan yaitu pelarian, kesenangan dan gairah (Menon dan Kahn, 2002; Mathwick et al., 2001). Studi Bruner dan Kumar (2005) serta Dahlberg et al. (2003) menyatakan enjoyment (kenyamanan) merupakan faktor utama yang memengaruhi keputusan pembelian online. Xiang et al. (2016) menyatakan bahwa kenyamanan berpengaruh signifikan terhadap perilaku pembelian impulsif. 


\subsection{Perilaku Pembelian online secara Impulsif}

Keinginan seseorang untuk membeli tanpa perencanaan dapat diartikan sebagai pembelian secara tiba-tiba, dan tanpa berfikir terlebih dahulu saat pengambilan keputusan didapat secara instan tanpa pertimbangan (Kazempour dan Lotfizadeh, 2017). Pembelian impulsif sebagai perilaku yang menjadi salah satu fenomena yang sering terjadi. Tidak jarang seseorang melakukan pembelian tidak terencana secara spontan dan hanya menggunakan perasaan setelah mendapatkan stimulus (Liu et al., 2013). Kebanyakan pembelian produk baru dihasilkan dari pembelian impulsif daripada pembelian yang direncanakan (Kacen dan Lee, 2002; Darmawan (2017) dan menurut Rook (1987), pembelian secara tiba-tiba tidak terencana terjadi ketika konsumen tiba-tiba merasakan dorongan tak tertahankan untuk membeli sesuatu dengan cepat. Pembelian impulsif terkait tindakan reaktif dan komponen afektif (Huang, 2015). Konsumen dengan keadaan yang dimaksud akan memiliki pengetahuan rendah terhadap keputusan pembelian dan akan melakukannya di luar kendali karena hal tersebut reaksi terhadap rangsangan sehingga proses kognitif terjadi (Ferrinadewi dan Darmawan, 2004). Perilaku pembelian secara tiba-tiba tidak terencana akan terjadi bila seseorang mempunyai keinginan untuk membeli (Floh dan Madlberger, 2013).

\section{Metode Penelitian}

Populasi untuk penelitian ini merupakan pelanggan yang pernah melakukan pembelian di Lazada. Penelitian ini menggunakan teknik non-probability sampling dengan metode sampel purposive sampling. Kriteria sampel adalah pelanggan yang pernah melakukan pembelian secara online Lazada lebih dari satu kali, dan usia diatas 17 tahun sampai 50 tahun. Responden berasal dari kota Sidoarjo dan sekitarnya. Data primer dengan menyebarkan kuisioner kepada seluruh responden. Sumber data tersebut akan dikumpulkan menggunakan pertanyaan tertutup oleh peneliti. Skala likert akan digunakan pada penelitian ini, skala penelitian tersebut adalah dari skala sangat tidak setuju sekali” dengan nilai satu sampai "sangat setuju setuju sekali" dengan nilai delapan. Kuesioner berbasis web online dibuat 
menggunakan aplikasi dari google form. Responden diundang melalui email, Whatsapp, Facebook, dengan pesan berisi link yang terhubung ke website yang berisi pertanyaan-pertanyaan dalam kuisioner, kemudian diisi. Sampel ditargetkan sebanyak 120 peserta dari penelitian ini diharapkan memenuhi persyaratan untuk mengikuti penelitian ini.

Variabel pertama di penelitian ini adalah pengalaman yang berarti pengalaman pembelian online yang membantu mengurangi ketidakpastian pengguna. Indikator yang digunakan berdasarkan teori dari Schmitt (1999) yang meliputi sense, feel, think, act dan relate.

Variabel bebas selanjutnya adalah variabel keamanan. Variabel ini tentang kemampuan sistem online yang mampu melakukan kendali dan penjagaan keamanan terhadap transaksi data. Variabel ini diukur berdasarkan Chellappa dan Pavlou (2002) yang menyatakan ada lima indikator, yaitu (1) tingkat keyakinan bahwa informasi hanya akan sampai ke pihak yang tepat; (2) tingkat keyakinan bahwa pihak yang tidak pantas tidak akan melihat atau menyimpan informasi konsumen; (3) tingkat keyakinan bahwa pengecer tidak akan mengungkapkan informasi konsumen kepada orang lain; (4) tingkat keyakinan bahwa pihak yang tidak pantas tidak akan memanipulasi informasi konsumen selama bertransaksi; (5) tingkat kepercayaan keseluruhan atas keamanan transaksi.

Variabel bebas selanjutnya adalah kemudahan penggunaan. Variabel ini berkaitan dengan keyakinan pengguna bahwa sistem tidak sulit dalam cara menggunakannya sehingga tidak perlu usaha. Mereka mengharapkan website sudah tertata dan diolah dengan baik sehingga mudah untuk dioperasikan dan tidak terlalu rumit akan lebih mempermudah pengguna. Alat ukurnya berdasarkan indikator dari Davis (2000), yang menyekat variabel ini dengan empat indikator, yaitu (1) ease to learn - teknologi informasi mudah dipelajari; (2) ease to use - teknologi informasi mudah digunakan; (3) clear and understandable - teknologi informasi jelas dan mudah dimengerti; (4) become skillful.

Variabel bebas keempat adalah kenyamanan yang mengarah kepada 
motivasi intrinsik yang memastikan seberapa jauh kepuasan seseorang ketika berinteraksi dengan lingkungan yang dalam hal ini adalah belanja secara online dan memiliki berbagai tawaran yang menarik. Variabel ini disusun dari tiga indikator yaitu pelarian (escapism), kesenangan (pleasure) dan gairah (arousal) (Menon dan Kahn, 2002; Mathwick et al., 2001).

Variabel terikat adalah pembelian impulsif pada marketplace Lazada (Y) Pembelian Impulsif di Lazada ini berhubungan dengan pembelian secara tiba-tiba dan tidak terencana oleh pembeli. Variabel ini tersusun berdasarkan delapan indikator yang berasal dari Rook (1987) menyatakan delapan dimensi pembelian impulsif, yang dijelaskan sebagai berikut, (1) the spontaneous urge to buy pembelian impulsif terjadi setelah seseorang merasakan dorongan spontan yang tidak terduga yang dalam banyak kasus merupakan respons terhadap promosi iklan atau konfrontasi visual; (2) power and compulsion-hal tersebut menjelaskan kekuatan menjadi dasar dorongan untuk melakukan pembelian dan membuat dorongan untuk bertindak secara cepat terkait produk sambil tidak mempedulikan faktor-faktor lain; (3) excitement-dorongan dalam membeli yang dirasakan konsumen dapat menjadi awal mula kesenangan secara pribadi dan dapat terjadi pada tingkatan yang berbeda-beda pada setiap konsumen; (4) synchronicity-ini menggambarkan kesan seperti keajaiban yang terjadi pada saat konsumen merasakan kompatibilitas instan, bahwa mereka hadir di tempat dan lingkungan yang tepat pada saat yang tepat, saat mereka menemukan produk dan menganggap pertemuan itu sebagai kebetulan; (5) product animation - setiap produk memiliki daya tariknya sendiri-sendiri dan konsumen sering kali tertarik pada daya tarik misterius produk tersebut, sehingga menjadikan konsumen merasa 'terhipnotis' untuk membelinya; (6) hedonic elements - pembelian impulsif mengandung unsur hedonistik yang menimbulkan perasaan baik dan buruk seperti kepuasan atau rasa bersalah; (7) conflict-pembelian impulsif dapat mengakibatkan konflik emosional pada diri konsumen. Mereka merasakan dua perasaan yang saling bertentangan, kesenangan dan rasa bersalah, karena pembelian impulsif dan pembelian spontan yang ditimbulkannya dapat bertentangan dengan peraturan pribadi mereka sendiri; (8) consequence-keinginan yang besar untuk melakukan pembelian, terutama dalam pembelian 
impulsif, dapat menyebabkan konsumen mengabaikan konsekuensi yang mungkin timbul.

Hasil penelitian ini dihasilkan oleh olah data yang menggunakan teknik analisis regresi linier berganda. Uji t bertujuan untuk mengetahui pengaruh variabel bebas secara sendiri-sendiri terhadap variabel terikat. Sebagai pendukung analisis, dilakukan uji $\mathrm{F}$ dan pengukuran koefesien determinasi. Uji $\mathrm{F}$ bertujuan untuk mengetahui pengaruh seluruh variabel bebas secara bersama-sama terhadap variabel terikat. Uji Koefisien Determinasi $\left(\mathrm{R}^{2}\right)$, bertujuan untuk menilai kemampuan model dan menjelaskan jenis variabel terikat. Dapat dikatakan uji tersebut untuk mengetahui besarnya sumbangan variabel bebas terhadap variabel terikat, dengan nilai adjusted $\mathrm{R}$ square diantara 0 hingga 1.

\section{Hasil Dan Pembahasan}

Penelitian ini memiliki responden dengan profil yang berdasarkan usia, jenis kelamin, pekerjaan, pendidikan dan frekuensi belanja secara online. Responden pada penelitian ini ada 120 orang dengan uraian deskripsi profil responden ditunjukkan Tabel 1 berikut ini.

Tabel 1. Karakteristik Responden 


\begin{tabular}{|c|c|c|c|c|}
\hline No & Karakteristik & Deskripsi & Frekuensi & Persentase \\
\hline \multirow{2}{*}{1} & \multirow{2}{*}{ Jenis Kelamin } & Laki-laki & 42 & $35 \%$ \\
\hline & & Perempuan & 78 & $65 \%$ \\
\hline \multirow{5}{*}{2} & \multirow{5}{*}{ Usia } & $17-23$ tahun & 24 & $20 \%$ \\
\hline & & $24-30$ tahun & 46 & $38,3 \%$ \\
\hline & & $31-37$ tahun & 37 & $30,8 \%$ \\
\hline & & $38-44$ tahun & 9 & $7,5 \%$ \\
\hline & & $45-50$ tahun & 4 & $3,3 \%$ \\
\hline \multirow{4}{*}{3} & \multirow{4}{*}{ Pendidikan } & SMA & 49 & $40,8 \%$ \\
\hline & & D3 & 13 & $10,8 \%$ \\
\hline & & $\mathrm{S} 1$ & 51 & $42,5 \%$ \\
\hline & & $\mathrm{S} 2$ & 7 & $5,8 \%$ \\
\hline \multirow{5}{*}{4} & \multirow{5}{*}{ Pekerjaan } & Mahasiswa & 29 & $24,2 \%$ \\
\hline & & Pegawai Swasta & 33 & $27,5 \%$ \\
\hline & & Wiraswasta & 22 & $18,3 \%$ \\
\hline & & PNS & 24 & $20 \%$ \\
\hline & & Ibu Rumah Tangga & 12 & $10 \%$ \\
\hline \multirow{3}{*}{5} & \multirow{3}{*}{$\begin{array}{c}\text { Frekuensi } \\
\text { Belanja di } \\
\text { Lazada }\end{array}$} & $1-2 x$ & 43 & $35,8 \%$ \\
\hline & & $3-5 x$ & 38 & $31,6 \%$ \\
\hline & & Terlalu sering & 39 & $32,5 \%$ \\
\hline
\end{tabular}

Sumber: Hasil olah SPSS

Dari Tabel 1 diketahui bahwa responden lebih didominasi oleh responden wanita $(65 \%)$, berusia antara 24 - 37 tahun $(83 \%)$, pendidikan SMA dan S1 $(83,3 \%)$, pekerjaan pegawai swasta $(27,5 \%)$, frekuensi belanja di Lazada $1-2 x$ $(35,8 \%)$. Deskripsi ini dapat menjadi gambaran bagi target pasar yang perlu dikembangkan lebih lanjut.

Selanjutnya uji reliabilitas bertujuan untuk mengukur suatu kuisioner yang dapat dipercaya yang diamati masing-masing variabel. Uji reliabilitas dinyatakan reliabel apabila nilai cronbach Alpha > taraf signifikansi 60\% atau 0,6 maka kuesioner tersebut reliabel dan kebalikannya (Malhotra, 2007).

Tabel 2. Uji Reliabilitas

\begin{tabular}{|c|c|c|}
\hline Variabel & N of item & Cronbach's Alpha \\
\hline Pengalaman & 5 & 0,843 \\
\hline Keamanan & 5 & 0,837 \\
\hline Kemudahan Penggunaan & 4 & 0,796 \\
\hline Kenyamanan & 3 & 0,803 \\
\hline Perilaku Pembelian Impulsif & 8 & 0,791 \\
\hline
\end{tabular}

Sumber: Hasil olah SPSS 
Dari uji tersebut diketahui semua variabel dinyatakan reliabel karena nilai cronbach Alpha > taraf signifikansi $60 \%$ atau 0,6. Selanjutnya untuk menjelaskan pengaruh antar variabel pengalaman, keamanan, kemudahan pengunaan, kenyamanan terhadap variabel terikat yaitu variabel perilaku pembelian impulsif. digunakan uji hipotesis seperti pada Tabel 3 berikut ini.

Tabel 3. Uji t (Coefficients $\left.{ }^{\mathrm{a}}\right)$

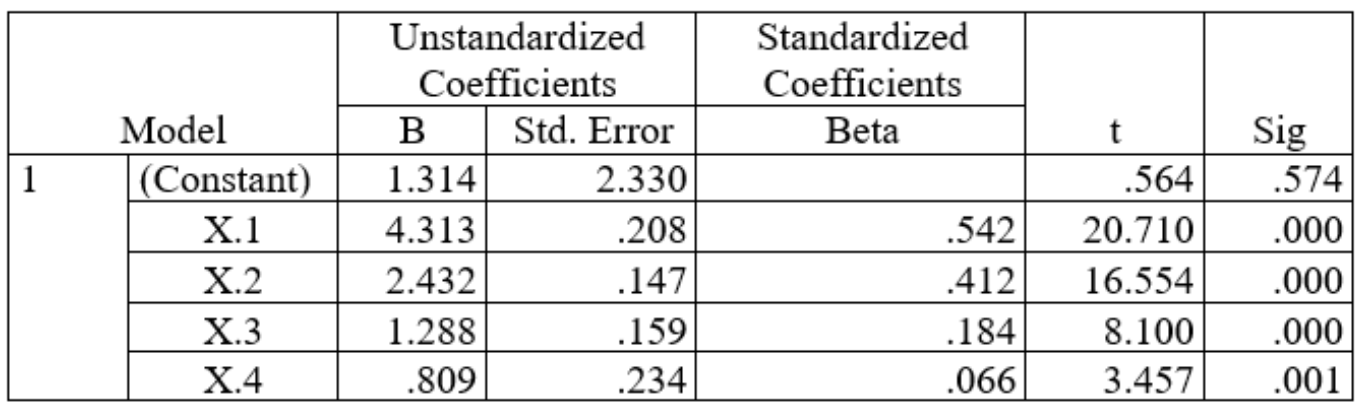

Sumber: Hasil olah SPSS

Dari Tabel 3 dapat diketahui bahwa setiap variabel bebas berpengaruh signifikan secara parsial terhadap perilaku pembelian impulsif. Dengan demikian hipotesis pertama, kedua, ketiga dan keempat dinyatakan diterima dan dapat dibuktikan kebenarannya. Tabel 3 menunjukkan persamaan regresi sebagai berikut: $\mathrm{Y}=1,314+4,313(\mathrm{X} .1)+2,432(\mathrm{X} .2)+1,288(\mathrm{X} .3)+0,809$ (X.4). Persamaan regresi menunjukkan variabel pengalaman adalah variabel bebas yang berpengaruh dominan terhadap perilaku pembelian impulsif.

Tabel 4. Hasil Uji F (ANOVA)

\begin{tabular}{|l|l|r|r|r|r|c|}
\hline \multicolumn{2}{|l|}{ Model } & \multicolumn{1}{c|}{$\begin{array}{c}\text { Sum of } \\
\text { Squares }\end{array}$} & df & Mean Square & F & Sig. \\
\hline \multirow{3}{*}{1} & Regression & 9819.963 & 4 & 2454.991 & 670.558 & $.000^{\mathrm{b}}$ \\
\cline { 2 - 7 } & Residual & 421.029 & 115 & 3.661 & & \\
\cline { 2 - 8 } & Total & 10240.992 & 119 & & & \\
\hline
\end{tabular}

Sumber: Hasil olah SPSS

Dapat diketahui dari tabel 4 bahwa nilai $F_{\text {hitung }}$ sebesar 670,558 dengan signifikansi 0.000 , dapat disimpulkan bahwa pada taraf nyata $\alpha=0.05$ seluruh varibel bebas mempunyai pengaruh yang signifikan secara bersama-sama terhadap perilaku pembelian impulsif. 
Tabel 5. Koefisien Determinasi (Model Summary ${ }^{b}$ )

\begin{tabular}{|c|r|r|r|r|r|}
\hline Model & \multicolumn{1}{|c|}{$\mathrm{R}$} & R Square & $\begin{array}{c}\text { Adjusted R } \\
\text { Square }\end{array}$ & $\begin{array}{c}\text { Std. Error of } \\
\text { the Estimate }\end{array}$ & $\begin{array}{c}\text { Durbin- } \\
\text { Watson }\end{array}$ \\
\hline 1 & $.979 \mathrm{a}$ & .959 & .957 & 1.91340 & 2.008 \\
\hline
\end{tabular}

Sumber: Hasil olah SPSS

Berdasarkan tabel 5 dapat dilihat bahwa nilai nilai adjusted R squared sebesar 0,957 yang artinya bahwa regresi berganda pada penelitian ini dengan variabel bebas pengalaman, keamanan, kemudahan penggunaan dan kenyamanan telah memberikan kontribusi sebesar $95,7 \%$ terhadap variabel terikat yaitu perilaku pembelian impulsif, sedangkan sisanya sebesar $4,3 \%$ ditentukan oleh variabel yang lain.

Dari hasil penelitian yang telah dijabarkan telah diperoleh jawaban dari hipotesis sebelumnya. Hipotesis pertama menyatakan bahwa pengalaman memiliki pengaruh secara nyata terhadap perilaku pembelian impulsif. Temuan ini mendukung studi dari beberapa peneliti seperti Parasuraman dan Zinkhan (2002); Mathwick et al. (2001); Elliot dan Fowell (2000); dan (Shim et al., 2001). Pada dasarnya mereka menyatakan bahwa pengalaman berbelanja dapat memberikan pengaruh terhadap perilaku lanjutan seperti perilaku belanja online. Perilaku berkelanjutan sesuai dengan kondisi di penelitian ini bahwa para responden pernah melakukan transaksi sebelumnya di Lazada. Pembelian impulsif termasuk dalam kategori perilaku berkelanjutan.

. Hipotesis kedua menyatakan bahwa keamanan bertransaksi mempunyai pengaruh yang signifikan terhadap perilaku pembelian impulsif. Hal ini sesuai dengan temuan dari Pavlou (2001) dan Zhang dan Von Dran (2002). Faktor keamanan memiliki peran untuk membentuk kepercayaan pengguna dengan memastikan tidak ada tindakan diluar penyelewengan data pengguna dan transaksi data yang mudah rusak (Mardikaningsih dan Sinambela, 2016). Pengguna mau membagikan informasi data pribadi dengan perasaan aman saat adanya keyakinan bahwa keamanan terjamin. Kesan responden terhadap keamanan menjadi faktor pendorong mereka melakukan pembelian impulsif di situs e-commerce.

Hipotesis ketiga menyatakan bahwa kemudahan penggunaan memiliki pengaruh 
signifikan terhadap perilaku pembelian impulsif. Temuan ini sesuai dengan studi dari Chen dan Li (2007); Yoon dan Sagynov. (2015); dan Kucukusta et al. (2015). Desain sistem yang memudahkan pengguna sistem memiliki peluang besar untuk diterima dan dikuasai oleh para pengguna. Selain itu hal tersebut akan membuat penghematan waktu dan usaha konsumen. Meski pada beberapa kejadian berbelanja online akan dinyatakan gagal bila pemesanan terlalu rumit (Lim dan Dubinsky, 2004).

Hipotesis keempat menyatakan bahwa kenyamanan berpengaruh signifikan terhadap perilaku pembelian impulsif di Lazada. Temuan ini sesuai dengan studi dari Dahlberg et al. (2003); Bruner dan Kumar (2005); dan Xiang et al. (2016) yang menyatakan bahwa kenyamanan mempunyai pengaruh signifikan terhadap perilaku pembelian impulsif. Menurut Verhagen dan van Dolen (2011) ketika konsumen mengalami lebih banyak dorongan untuk membeli, mereka cenderung melakukan pembelian impulsif. Begitu pun ketika konsumen menghadapi rangsangan di situs belanja (secara langsung, atau tidak langsung melalui efek evaluasi internal), mereka mengalami dorongan untuk membeli secara impulsif (Shen dan Khalifa. 2012). Hubungan antara keinginan untuk membeli secara impulsif dan pembelian impulsif telah digambarkan sebagai efek berantai pada tahap respons di studi pembelian impuls offline dan online. Adanya kenyamanan yang dirasakan konsumen menyebabkan mereka lebih mudah untuk memutuskan pembelian. Menurut studi dari Verhagen dan van Dolen (2011) serta Shen dan Khalifa menemukan hubungan positif dan signifikan antara dorongan untuk membeli secara impulsif dan perilaku pembelian impulsif online.

\section{Kesimpulan}

Hasil yang diperoleh pada penjelasan dibab sebelumnya maka peneliti dapat menghasilkan beberpa kesimpulan pada penelitian ini, berikut adalah beberapa kesimpulan yang diperoleh peneliti:: (1) pengalaman memiliki pengaruh yang signifikan terhadap perilaku pembelian impulsif di Lazada; (2) keamanan memiliki pengaruh yang signifikan terhadap perilaku pembelian impulsif di Lazada; (2) kemudahan penggunaan memiliki pengaruh yang signifikan terhadap perilaku 
pembelian impulsif di Lazada; (3) kenyamanan memiliki pengaruh yang signifikan terhadap perilaku pembelian impulsif di Lazada. Selain itu secara simultan, keempat variabel bebas tersebut juga memiliki pengaruh yang signifikan terhadap perilaku pembelian impulsif di Lazada. Variabel pengalaman merupakan variabel yang berpengaruh dominan. Konsumen yang melakukan pembelian secara spontan memiliki kecenderungan mereka tidak terlalu membutuhkan barang tersebut. Pengalaman, keamanan, kemudahan penggunaan dan kenyamanan menjadi pendorong utama di penelitian ini untuk melakukan pembelian impulsif di Lazada. Hal ini seharusnya menjadikan Lazada berupaya untuk selalu mengupdate demi ketercapaian user friendly untuk mendesain sistem sehingga selain memiliki daya tarik tampilan, juga memiliki kemudahan dan keamanan sistem. Lazada diharapkan bisa mempertahankan kemudahan dalam hal pengunaan dari berbagai fitur-fitur yang ada juga kemudahan dan keamaan dalam proses transaksi jual beli, hal ini terkait dengan pembayaran yang terjamin keamanannya. Lazada harus tetap mempertahankan menjadi media dan tempat belanja yang lebih ingin dikunjungi oleh konsumen Indonesia khususnya konsumen-konsumen yang ingin berbelanja online. Kenyamanan dapat distimulus lebih besar melalui program promosi yang menarik sesuai dengan target pasar yang tepat. Pengguna ponsel sebagai pengguna mayoritas menjadi sasaran pengguna utama sistem tersebut agar lebih sering melakukan pembelian secara impulsif. Untuk variabel keamanan perlu ditingkatkan kembali fitur pembayaran yang lebih mudah, cepat dan aman. Dengan adanya pembayaran yang lebih praktis namun tetap aman akan menyebabkan konsumen lebih sering berbelanja. Selain itu Lazada juga dapat mengembangkan kerjasama dengan bentuk pembayaran virtual-virtual lainnya.

\section{DAFTAR PUSTAKA}

Bruner II GC, Kumar A. (2005). Explaining consumer acceptance of handheld Internet devices. J Bus Res; 58(5), 553 \pm 8 .

Chellappa, R.K. \& P.A. Pavlou. (2002). Perceived Information Security, Financial Liability, and Consumer Trust in Electronic Commerce Transactions. Logistics Information Management, 15(5/6), 358-368. 
Chen, H \& Y. Li. (2007). An Empirical Research of Factors Influencing the DecisionMaking of Chinese Online Shoppers. in IFIP International Federation for Information Processing, Volume 251, Integration and Innovation Orient to ESociety. Volume 1, Wang, W. (Eds), (Boston: Springer), 202-210.

Childers, T.L., Carr, C.L., Peck, J. \& Carson, S. (2001). Hedonic and utilitarian motivations for online retail shopping behavior, Journal of Retailing, 77 (4), 511-35.

Cho, Yoon C. \& E. Sagynov. (2015). Exploring Factors that Affect Usefulness, Ease of Use, Trust, and Purchase Intention in The Online Environment. International Journal of Management \& Information Systems, 19(1), 21-36. Dahlberg, T., Mallat, N., \& Öörni, A. (2003). Trust enhanced technology acceptance model - consumer acceptance of mobile payment solutions. In Mobility Roundtable, Stockholm, Sweden, May 22-23.

Darmawan, D. (2004). Pemasaran Internet dan Penerapannya, Jurnal Bisnis, Ekonomi dan Sosial, 4(2), 52-73.

Darmawan, D. (2005). Top of Mind Brand Vs Bottom of Mind Brand, Jurnal Media Komunikasi Ekonomi dan Manajemen, 3(3), 51-57.

Darmawan, D. (2008). Internet Marketing: Menggeser Pemasaran Konvensional. Jurnal Akuntansi, Manajemen Bisnis dan Sektor Publik, 4(2), 128-148.

Darmawan, D. (2012). Manajemen Informasi, Metromedia, Surabaya.

Darmawan, D. (2017). Manajemen Ritel, PT. Revka Prima Media, Surabaya.

Darmawan, D. (2021 ${ }^{\mathrm{a}}$ ). Understanding Impulsive Buying Behavior in Marketplace, Journal of Social Science Studies 1(1), $11-18$.

Darmawan, D. $\left(2021^{\mathrm{b}}\right)$. Pencapaian Kepuasan dan Loyalitas Pelanggan melalui Strategi Pemasaran Berdasarkan Pengalaman (Studi Kasus Pelanggan Rumah Makan Ayam Bakar Wong Solo Di Mojokerto), Jurnal Manajemen, Bisnis, dan Kewirausahaan, Vol. 1, No. 1, Mei 2021, 1-13.

Davis, F.D. (1989). Perceived Usefulness, Perceived Ease of Use, and User Acceptance of Information Technology, MIS Quarterly, 13(3), 319-340.

Davis, F. D., Bagozzi, R.P., \& Warshaw, P.R. (1992). Extrinsic and instrinsic motivation to use computers in the workplace. Journal of Applied Social Psychology, 22(14), 1111-1132. 
Elliot, S. \& Fowell, S. (2000). Expectations versus reality: a snapshot of consumer experiences with Internet retailing, International Journal of Information Management, 20(5), 323-36.

Eroglu, S.A., K.A. Machleit, \& L.M. Davis. (2001). Atmospheric qualities of online retailing: A conceptual model and implications. Journal of Business Research, 54(2), 177-184.

Ferrinadewi, E. \& Darmawan, D. (2004). Perilaku Konsumen: Analisis Model Keputusan, Universitas Atma Jaya, Yogyakarta.

Floh, A. \& Madlberger, M. (2013). The role of atmospheric cues in online impulse-buying behavior. Electronic Commerce Research and Applications 12(6), 425-439.

Gefen, D. (2000). E-commerce: the role of familiarity and trust. Omega, 28(6), 725-737.

Huang, L. T. (2015). Flow and social capital theory in online impulse buying. Journal of Business Research 69(6), 2277-283.

Holbrook, M.B. (1994). The nature of customer value: an axiology of services in the consumption experience, in Rust, R.T. and Oliver, R.L. (Eds), Service Quality: New Directions in Theory and Practice, Sage, Newbury Park, CA, 21-71.

Iskandar, Mochamad. \& D. Darmawan. (2003). Strategi Pemasaran, IntiPresindo Pustaka, Bandung.

Kacen, Jacqueline J., \& J. A. Lee. (2002). The Influence of Culture on Consumer Impulse Buying Behavior. Journal of Consumer Psychology, 12(2), 163-176.

Karina, Ana., Toni Baskoro K. \& D. Darmawan. (2012). Pengantar Psikologi, Addar Press, Jakarta

Kazempour, Y. \& Lotfizadeh, F. (2017). The Impact of Situational Factors (Store, Personal) on Urge to Buy Impulsively and Impulsive Buying Behavior. European Journal of Business and Innovation Research 5(4), 12-27.

Khasanah, Hikmahtul, Setya Arum, D. Darmawan. (2010). Pengantar Manajemen Bisnis, Spektrum Nusa Press, Jakarta.

Kucukusta, Rob Law, Alia Besbes, \& Patrick Legohérel. (2015). Re-examining perceived usefulness and ease of use in online booking: The case of Hong Kong online users, International Journal of Contemporary Hospitality Management, 27(2), 185-198, https://doi.org/10.1108/IJCHM-09-2013-0413. 
Lim, H. \& A.J. Dubinsky. (2004). Consumers' perceptions of e- shopping characteristics: an expectancy- value approach, Journal of Services Marketing, 18(7), 500-513.

Liu, Y., H. Li, \& F. Hu. (2013). Website attributes in urging online impulse purchase: An empirical investigation on consumer perceptions. Decision Support Systems, 55(3), 829-837.

Malhotra, Naresh. (2007). Marketing Research: an applied orientation, pearson education, inc., $5^{\text {th }}$ edition. New Jersey: USA.

Mardikaningsih, R. \& E. A. Sinambela. (2016). Peranan Komunikasi Pemasaran, Citra Merek dan Kepercayaan Merek terhadap Kesetiaan Merek, Jurnal Ilmu Manajemen, 2(1), 33-52.

Masitoh, D., D. Darmawan. E. A. Sinambela. (2017). The Effect of Service Quality and Trust on Customer Loyalty of Warung Apung Rahmawati of Mojokerto Branch, Jurnal Agrimas, 1(2), 107-114.

Mathwick, C., Malhotra, N.K. \& Rigdon, E. (2001). Experiential value: conceptualization, measurement and application in the catalog and Internet shopping environment, Journal of Retailing, 77(1), 39-56.

Menon, S. \& Kahn, B. (2002). Cross-category effects of induced arousal and pleasure on the Internet shopping experience, Journal of Retailing, 78(1), 31-40.

Nurmalasari, D., D. Darmawan, B. Utomo. (2018). The Role of Service Quality and Trust on The Loyalty of Blood Donors in Blood Transfusion Unit PMI Surabaya City, Prosiding, Seminar Nasional PPPI Wilayah Provinsi NTB 27 Oktober 2018, 501-513.

Parasuraman, A. \& Zinkhan, G.M. (2002). Marketing to and serving customers through the Internet: an overview and research agenda, Journal of the Academy of Marketing Science, 30(4), 286-95.

Park, E. J. Kim, E. Y., Funches, V. M., \& Foxx, W. (2012). Apparel product attributes, web browsing, and e-impulse buying on shopping websites. Journal of Business Research 65(11), 1583-1589.

Park, Chung-Hoon. \& Young-Gul Kim. (2006). The Effect of Information Satisfaction and Relational Benefit on Consumers Online Site Commitments, 
Journal of Electronic Commerce in Organizations, 4 (1), 70-90.

Pavlou, P.A. (2001). Integrating Trust in Electronic Commerce with the Technology Acceptance Model: Model Development and Validation, In Proceedings of the 7th Americas Conference on Information Systems, Boston, MA, 816-822.

Purnamasari, E., D. Darmawan, D. Baskara. (2002). Bauran Pemasaran dan Kualitas Layanan serta Pengaruhnya terhadap Kepuasan dan Loyalitas Pelanggan, Jurnal Ilmu Manajemen, 3(1), 34-46.

Raman, Arasu, \& A. Viswanathan. (2011). Web Services and e-Shopping Decisions: A Study on Malaysian e-Consumer. IJCA Special Issueon: Wireless Information Networks \& Business Information System, 2, 54-60.

Rook, Dennis W. (1987). The Buying Impulse, Journal of Consumer Research, 14(20), 189-199, https://doi.org/10.1086/209105.

Schmitt, B. H. (1999). Experiential Marketing: How to Get Customer to Sense, Feel, Think, Act, and Relate to Your Company and Brands, New York: The Free Press. Setyaningsih \& D. Darmawan. (2004). Pengaruh Citra Merek terhadap Efektifitas Iklan, Jurnal Media Komunikasi Ekonomi dan Manajemen, 2(3), 41-49

Shen, K.N. \& M. Khalifa. (2012). System design effects on online impulse buying. Internet Research, 22(4), 396-425.

Shim, S \& Drake, M. F. (1990). Consumer intention to utilize electronic shopping, Journal of Direct Marketing. 4(3), 22-33.

Shim S, Eastlick MA, Lotz SL, Warrington P (2001). An online prepurchase intentions model: The role of intention to search. J. Retail., 77(3), 397-416.

Sjamsi, N. \& D. Darmawan. (2004). Peran Startegis Layanan pada Penyelenggaraan Pelayanan Publik, Jurnal Administrasi Publik, 1(1), 83-95.

Van der Heijden, H. (2003). Factors Influencing the Usage of Websites: The Case of a Generic Portal in the Netherlands, Information \& Management, 40(6), 541-549.

Verhagen, T. \& W. van Dolen. (2011). The influence of online store beliefs on consumer online impulse buying: A model and empirical application. Information \& Management, 48(8), 320-327.

Vijayasarathy, L.R. (2004). Predicting Consumer Intentions to Use On-Line 
Shopping: The Case of an Augmented Technology Acceptance Model, Information \& Management, 41(6),747-762.

Weber, K. \& Roehl, W. S. (1999). Profiling People Searching for dan Purchasing Travel Products on the World Wide Web, Journal of Travel Research, 291-298.

Xiang, L., Zhenga, X., Lee, M. K. O., \& Zhao, D. (2016). Exploring consumers' impulse buying behavior on social commerce platform: The role of parasocial interaction. International Journal of Information Management 36(3), 333-347.

Yoon, S. Joon. (2002). The antecedents and consequences of trust in onlinepurchase decisions. Journal of Interactive Marketing, 16(2), 47-63.

Zhang, P. \& G.M. Von Dran. (2002). User Expectations and Rankings of Quality Factors in Different Web Site Domains, International Journal of Electronic Commerce, 6(2), 9-33. 